\title{
General and specific combining abilities of local common bean varieties and cultivars
}

\author{
V.P. da Silva ${ }^{1}$, M.A.A. Barelli², J.P.E. Lira ${ }^{3}$, M.J. Arruda ${ }^{4}$, \\ J. P. Poletine ${ }^{5}$ and L.G. Neves ${ }^{2}$ \\ ${ }^{1}$ Programa de Pós-Graduação em Biodiversidade Amazônica e Biotecnologia, \\ Rede Bionorte Universidade do Estado de Mato Grosso, Cáceres, Brasil. \\ ${ }^{2}$ Departamento de Agronomia, Universidade do Estado de Mato Grosso, \\ Cáceres, Brasil. \\ ${ }^{3}$ Programa de Pós-Graduação em Genética e Melhoramento de Plantas, \\ Universidade do Estado de Mato Grosso, Cáceres, MT, Brasil. \\ ${ }^{4}$ Faculdade de Ciências Biológicas e Agrárias, Universidade do Estado de Mato \\ Grosso, Cáceres, MT, Brasil. \\ ${ }^{5}$ Departamento de Ciências Agronômicas, Universidade Estadual de Maringá - \\ UEM, Campus de Umuarama, Umuarama, PR, Brasil.
}

Corresponding author: V.P. da Silva

E-mail: silvabiologo@ hotmail.com

Genet. Mol. Res. 17 (3): gmr18057

Received June 25, 2018

Accepted August 07, 2018

Published September 25, 2018

DOI http://dx.doi.org/10.4238/gmr18057

ABSTRACT. We examined the general and specific combining
abilities of common bean cultivars and varieties and tested promising
hybrid combinations for the development of productive strains. Two
cultivars (IPR Uirapuru and IPR Campos Gerais) and five local
varieties (BGU-1, BGU-7, BGU-13, BGU-25 and BGU-36) were
planted in a full diallel cross. Treatments were assessed based on a
randomized block design, with 10repetitions. The following variables
were assessed: mean number of days still emergence, mean number
of days till blooming, mean insertion height of the first pod, mean
final plant height, mean stem diameter, mean length of the pods,
mean number of pods per plant, mean number of seeds per pod, mean
number of seeds per plant, mean weight of 50 seeds and grain yield.
A Griffing statistical analysis was performed. Cultivar IPR Uirapuru
and the local variety BGU-36 were promising for most variables in
the general combining ability. Combinations IPR Uirapuru $x$ BGU-7,
IPR Uirapuru x BGU-1, BGU-7 x BGU-1, BGU-25 x BGU-13 and 
BGU-13 x BGU-36 were the most promising in the specific combining ability to generate highly productive strains.

Key words: Phaseolus vulgaris; diallel analysis; plant breeding; genetic effects

\section{INTRODUCTION}

The common bean (Phaseolus vulgaris) is one of the main legumes used for human consumption (Broughton et al., 2003; Demelash, 2018), being considered a major source of proteins, carbohydrates, micronutrients, vitamins and dietary fiber (Talukder et al., 2010). In order for this legume to continue to be a key part of human diet, it is necessary that new varieties be developed, attending the demands of production verticalization (Rocha et al., 2014).Genetic enhancement is the main tool to launch new cultivars in the market.

Bean breeding programs emphasize the exploration of genetic varieties through the hybridization of superior and contrasting cultivars. However, just as it happens all around the world, genetic variability in Brazil tends to decrease due to the intense cultivation of single cultivars or of cultivars coming from few parents (Tsutsumi et al., 2015). Bitocchiet al. (2013) found that Mesoamerican-origin bean cultivars have gone through drastic geneticdiversity reduction; approximately $72 \%$ of their diversity was lost during the domestication process.

Progeny ( $F_{1}$ hybrids) studies have been conducted after the hybridization process. Various methods were used to implement the diallel analysis model proposed by Griffing (1956) (Barelli et al., 2000; Gonçalves-Vidigal et al., 2008; Arunga, et al., 2010; Trindade et al., 2015; Moura et al., 2016). This analysis allows estimating parent's general combining ability (GCA) and specific combining ability (SCA) (Spragueand Tatum, 1942).

Genetic enhancement can improve creole material from a certain region, because this material presents properties and characteristics similar to that of commercial cultivars (Voysest et al.,1994). Incorporating highly productive local varieties into high-yield cultivars can help optimize production with low additional input (Fess et al., 2011).We examined the GCA and the SCA of various bean genotypes in diallel crosses, to search forthe most promising combinations for the production of productive strains.

\section{MATERIAL AND METHODS}

Seven common bean parents, including five local varieties (BGU-1, BGU-7, BGU13, BGU-25 and BGU-36) of Phaseolus vulgaris from the Active Germoplasm Bank of the State University of Mato Grosso, Caceres Campus, as well as two commercial cultivars: IPR Campos Gerais and IPR Uirapuru from the Agronomic Institute of Paraná (IAPAR) were used to obtain $F_{1}$ hybrids in a full diallel scheme, without reciprocals. To obtain hybrids $\left(\mathrm{F}_{1}\right.$ generation), crosses were made with emasculation of flower buds with interlacing, requiring four successive parent plant seedings during 2016, from January through September. Crosses were made in the morning (07:00 to 10:00 h) and in the afternoon(15:00 to 18:00 h). From October to December, crosses were made in the afternoon until 18:30 due to daylight summer time, this being one hour earlier compared to earlier months. Mean temperature during the crosses ranged from 20 to $34^{\circ} \mathrm{C}$. 
The performance of parents and $F_{1}$ hybrids was assessed from February to April 2017 in a screened greenhouse at Empresa Mato-Grossense de Pesquisa, Assistência e Extensão Rural (EMPAER), Caceres County, Mato Grasso State (16 43 '42" S and $57^{\circ} 40^{\prime} 51^{\prime}$ W). According to Köppen's classification, the characteristic climate in the region is tropical, hot and humid, with a dry winter (Awa). The rainfall period is from October to March and the dry season is from April to September (Neves et al., 2011).

Cultivation of parents and of their 21 hybrids was carried out in $5.0 \mathrm{~L}$ plastic potsfilled with the commercial substrate Topstrato $\mathrm{HT}^{\circledR}$. Mineral fertilizer was added before cultivation; $20 \mathrm{~g}$ of $\mathrm{N}, \mathrm{P}_{2} \mathrm{O}_{5}$ and $\mathrm{K}_{2} \mathrm{O}$ 4-14-8 was added to each vessel. Fertilization was started after 15 days by weekly applying nitrogen at a dose of $50 \mathrm{mg} / \mathrm{dm}^{3}$, usingammonium sulfate $\left[\left(\mathrm{NH}_{4}\right)_{2} \mathrm{SO}_{4}\right]$. Potassium $\left(\mathrm{K}_{2} \mathrm{SO}_{4}\right)$ was applied at a dose of $75 \mathrm{mg} / \mathrm{dm}^{3}$ at blooming.

A randomized block design, with 26 treatments and 10 repetitions, was adopted. The experimental units were composed of two vessels with two bean plants each. The following variables were assessed: mean number of days till emergence (EMERG) mean number of days to blooming (BLOOM), mean insertion height of the first pod (INSHEI), mean final plant height (MFPR), mean stem diameter (MSD), mean length of the pods (MLLP), mean number of pods per plant (MNPPL), mean number of seeds per pod (MNSP), mean weight of 50 seeds (MWS) and grain production (GP).

The methodology by Griffing (1956) - Method 2- was used in the diallel analysis; it analyzes the $\mathrm{p}(\mathrm{p}+1) / 2$ combinations, which correspond to parents and their crossing processes, without reciprocals. Parents were considered the fixed effect and only the experimental error resulted from the random effect. Conclusions in this research were limited to genotypes. The statistical analyses were conducted with the Genes software, version 2016.6.0 (Cruz, 2013).

\section{RESULTS AND DISCUSSION}

All assessed variables presented significant values at $1 \%$ probability in the $\mathrm{F}$ test (Table 1). This indicates genetic differences among the 21 hybrid combinations. This shows that the parents diverge from each other, which is an important feature for the success of a breeding program, because genetic variability favors the selection of promising materials (Carvalho et al., 2016).

The mean values of quadratic behaviors recorded for GCA effects were higher than the values of SCA in variables INSHEI and MLLP. This outcome indicates additive gene effects in the expression of these variables. The additive effects of INSHEI were previously reported by Barelli et al. (2000). According to the results of the aforementioned variables, the best option to enhance this population is intra populational.

The mean SCA values of quadratic components in EMERG, INSHEI, TNPP, MNSP, MNSPL, PMS and PG were higher than the GCA values; this implies non-additive type gene action. Inter populational enhancement with heterosis can, under these circumstances, provide superior genetic gains to these variables in comparison with intra populational enhancement strategies.

The assessed parents can be used either in intra or inter populational enhancement in BLOOM and MSD. Therefore, both the gene additive and non-additive effects were equally important, as can be observed by the relative proximity between the means of GCA and SCA quadratic effects (Table 1). 
Table 1 - Diallel analysis based on method 2, Model 2 by Griffing (1956) applied to the 11 variables: mean number of days till emergence (EMERG), mean number of days tillblooming (BLOOM), mean insertion height of the first pod (INSHEI), mean final plant height (MFPR), mean stem diameter (MSD), mean length of the pods (MLLP), mean number of pods per plant (MNPPL), mean number of seeds per pod (MNSP), Mean weight of 50 seeds (MWS) andgrain production (GP) in common beans, by specifying the effects of the general combining ability (GCA) and of the specific combining ability (SCA).

\begin{tabular}{|c|c|c|c|c|c|c|c|c|c|c|c|c|}
\hline \multicolumn{13}{|c|}{ Median Squares of Agronomic Variables } \\
\hline FV & GL & EMERG & BLOOM & INSHEI & MFPR & MSD & MLLP & TNPP & MNSP & MNPPL & MWS & GP \\
\hline Genotypes & 27 & $3.5776^{* *}$ & $28.6031^{\text {*** }}$ & $1247.6617 * *$ & $3.3764 * *$ & $3.8237^{* *}$ & $2.9373^{* *}$ & $107.9482 * *$ & $3.5976^{* *} *$ & $3949.1582 * *$ & $30.1584^{* *}$ & $88.5817 * *$ \\
\hline GCA & 6 & $2.6735 * *$ & $70.3735^{* *}$ & $4536.5231 * *$ & $10.0423 * *$ & $9.8533 * *$ & $10.6256^{* *}$ & $58.8970 * *$ & $9.7417 * *$ & $7812.7580^{* *}$ & $64.1581^{* * *}$ & $26.6140 * *$ \\
\hline SCA & 21 & $3.8359 * *$ & $16.6688^{* * *}$ & $307.9870 * *$ & $1.4719 * *$ & $2.1009 * *$ & $0.7407^{* *}$ & $121.9628 * *$ & $1.8421 * *$ & $2845.2726^{* *}$ & $20.4441 * *$ & $106.2867^{* *}$ \\
\hline Residue & 243 & 0.4487 & 2.0849 & 145.9691 & 0.1162 & 0.2814 & 0.1946 & 31.3799 & 0.7786 & 685.0527 & 5.4727 & 28.4130 \\
\hline \multicolumn{13}{|c|}{ Median squares of the effect } \\
\hline GCA & & 0.0046 & 2.0707 & 8480.3061 & 0.0417 & 0.4047 & 0.0465 & 3.1764 & 0.0394 & 26070.8685 & 1.7430 & 1.6197 \\
\hline SCA & & 0.1417 & 2.6819 & 1078.7568 & 0.2074 & 0.4269 & 0.0055 & 149.7706 & 0.3731 & 80963.2564 & 4.2271 & 114.2336 \\
\hline Residue & & 0.4487 & 2.0849 & 145.9691 & 0.1162 & 0.2814 & 0.1946 & 31.3799 & 0.7786 & 685.0527 & 5.4727 & 28.4130 \\
\hline
\end{tabular}

The GCA estimates allow breeders to obtain information about the concentration of favorable alleles; the greater the GCA magnitude, the higher the frequency of favorable alleles. Cruz et al. (2014) highlight that populations from crossing processes between highGCA parents lead to a higher frequency of favorable alleles; thus, they increase the possibility of finding promising strains. Therefore, it is necessary to look for hybrid combinations in which at least one parent records a high GCA value in order to choose the population.

We searched for hybrid combinations presenting higher means in INSHEI, MFPR, MSD, MLLP, TNPP, MNSP, MNSPPL, MWS and GP, in which at least one parent presented positive GCA values. This was done because these are the variables demanding the lowest means; i.e., they suggest EMERG and BLOOM reduction. Interestingly, at least one of the parents recorded negative GCA values (Table 2).

EMERG showed non-additive gene effects (Table 1), and parent BGU-36 had the greatest GCA magnitude (Table 2). This outcome allows this parent to be recommended for breeding programs, because it can increment seed vigor, since it enables faster seedling emergence. Parents BGU-25, BGU-13, BGU-1 and BGU-36 recorded negative BLOOM values: $g_{\mathrm{I}}-0.9714,-0.7047,-0.5381$ and -0.2047 , respectively (Table 2 ). This indicates that these parents help the development of crossing processes and of precocious individuals.

INSHEI is of fundamental importance for mechanized planting, since it facilitates harvest and prevents pods from coming in to contact with the soil; consequently, it causes less degradation in the product to be harvested (Velhoet al., 2017). According to our research, parents recommended for breeding programs to improve this variable are BGU-36 and IPR Campos Gerais, because they presented greater magnitudes: 12.2030 and 6.8252, respectively (Table 2 ).

Parents BGU-36 and BGU-7 presented magnitudes 0.3749 and 0.2735 , respectively in MFPR; thus, they are recommended when the focus is to obtain taller plants (Table 2). The non-additive gene effects were more frequent than the additive ones, since they showed higher GCA (0.2074) than SCA (0.0417) values (Table 1). Similar and divergent values of additive and non-additive gene action in this variable were previously reported by Gonçalves et al. (2015) and Barelli et al. (2000), respectively. 
Table 2 - Estimates of the general combining ability (GCA) effect on the 11 variables: mean number of days till emergence (EMERG), mean number of days till blooming (BLOOM), mean insertion height of the first pod (INSHEI), mean final plant height (MFPR), mean stem diameter (MSD), mean longitudinal length of pods (MLLP), mean number of pods per plant (MNPPL), mean number of seeds per plant (MNSP), mean number of seeds per pod (MNSP), mean weight of 50 seeds (MWS) and mean grain production (GP) in common bean. Standard deviation (SD) of the effects of two different parents.

\begin{tabular}{|c|c|c|c|c|c|c|c|c|c|c|c|}
\hline \multirow[b]{2}{*}{ GENOTYPES } & \multicolumn{11}{|c|}{ Assessed variables } \\
\hline & EMERG & BLOOM & INSHEI & MFPR & MSD & MLLP & TNPP & MNSP & MNPPL & MWS & GP \\
\hline IPR Uirapuru & -0.0031 & 1.5285 & 0.7907 & 0.1711 & 0.4588 & 0.0422 & 0.8198 & 0.4236 & 12.5071 & $\begin{array}{l}-0.1300 \\
\end{array}$ & 0.5434 \\
\hline BGU-7 & -0.0282 & 0.7507 & -2.4891 & 0.2735 & 0.4336 & -0.1988 & 1.3531 & 0.1217 & 12.9182 & -0.8413 & -0.2697 \\
\hline BGU-1 & 0.2224 & -0.5381 & -5.8202 & -0.3561 & -0.3155 & 0.6914 & -0.9634 & 0.0228 & -6.0817 & 0.3731 & -0.3584 \\
\hline BGU-25 & -0.0114 & -0.9714 & -5.7170 & -0.2831 & -0.0276 & -0.0879 & -0.4968 & 0.0695 & -0.2484 & -0.0583 & -0.3040 \\
\hline BGU-13 & 0.1967 & -0.7047 & -5.7926 & -0.4075 & -0.1292 & -0.2709 & -0.0134 & 0.0261 & -2.2595 & -1.1480 & -0.1846 \\
\hline BGU-36 & -0.0928 & -0.2047 & 12.2030 & 0.3749 & -0.0372 & -0.3029 & 0.3079 & -0.6701 & -14.2373 & 1.3836 & 0.9891 \\
\hline IPR Campos gerais & -0.0283 & 0.1396 & 6.8252 & 0.2272 & -0.0469 & 0.1269 & 0.3912 & 0.0061 & -0.5984 & 0.4210 & -0.4156 \\
\hline $\operatorname{DP}\left(g_{i}-g_{j}\right)$ & 0.0998 & 0.2152 & 1.8010 & 0.0508 & 0.0790 & 0.0657 & 0.8350 & 0.1315 & 3.9017 & 0.3487 & 0.7946 \\
\hline
\end{tabular}

Parents IPR Uirapuru and BGU-7 presented high mean stem diameter estimates (Table 2); thus, these parents can contribute to genetic gains in this variable. Velhoet al. (2017) emphasized that this variable plays an essential role in plant support, as larger diameters avoid bedding and facilitate mechanized harvest processes. MLLP presented additive gene action prevalence; BGU-1 parents recorded 0.6914, IPR Campos Gerais, 0.1269 and IPR Uirapuru, 0.042. Thus, they stood out among the others, due to their positive GCA values (Table 2). The additive gene action of this variable was previously evidenced in research conducted by Krause et al. (2012) with bean pods.

The non-additive gene effects were greater than the additive ones in TNPP, MNSP and MNSPPL. Different from results in our research, Gonçalves et al. (2015) reported additive gene effects of variables TNPP and MNSP. Barelli et al. (2000) highlighted that additive and non-additive gene effects are equally important in MNSPPL.

Among the aforementioned variables, parents IPR Uirapuru and BGU-7, in this order, were the ones presenting the greatest positive GCA magnitudes in TNPP, MNSP and MNSPPL (Table 2). Thus, when the idea is to gather parents for intercrossing to increase production components, these parents are the most recommended for inter populational enhancement with heterosis due to their non-additive gene effects.

Parent BGU-36 presented GCA values of 1.3836 in MWS and 0.9891 in GP; so it was recommended for breeding programs that focus on incrementing these variables. The non-additive action type expressed for these variables can be explained by the fact that some parents were previously selected in breeding programs focused on variables linked to production, as described by Cruz et al. (2014). Gonçalves-Vidigal et al. (2008) also found an effect of non-additive gene action on MWS and on GP in diallel crossing processes involving the following cultivars: BRSMG-Talismã, IPR Uirapuru, FT Soberano, BRS Campeiro, IAC Tybatã and IPR Juriti.

Thus, according to results recorded for the GCA effects, which set the mean performance of each parent in a series of crossing processes, besides being an estimate of the gene value, one can conclude that parents BGU-25 and BGU-36 should be favorites to be included in breeding programs focused on incrementing precocity. On the other hand, in case the aim of the breeding program is to increase yield, parents IPR Uirapuru, BGU-7 and BGU-36 are the most recommended, because they present the greatest magnitudes for variables associated with production. Either for precocity or yield, programs with such 
parents may include intra- or interpopulational methods in order to obtain promising hybrids or superior segregating cultivars in future generations.

The estimate of combining ability effects (Table 3) aids in the selection of the best combinations. Selection should prioritize the most favorable SCA estimates involving at least one of the parents, which must have shown favorable GCA effects (Griffing, 1956). The best hybrid contributions in EMERG originated from BGU-1 x BGU-36 and BGU-13 x BGU-36, which recorded SCA values: -1.1435 and -1.0928 , respectively. The hybrid combinations IPR Uirapuru x BGU-36 and BGU-1 xBGU-36in BLOOM presented the greatest negative magnitudes: -1.667 and -1.600 , respectively. Parent BGU-36 presented the best GCA result (Table 2). These results indicate that these specific combinations help diminish the number of days till germination and blooming.

The best combinations for INSHEI were BGU-7 x BGU-36 (9.8504), BGU-1 x IPR Campos Gerais (8.1293), IPR Uirapuru x BGU-36 (7.6395) and BGU-13 x BGU-36 (5.1229) (Table 3). Among the combinations mentioned above, the ones with parent 6 (BGU-36) presented more potential to be used in breeding programs, since this parent had the highest positive GCA estimate: 12.2030 (Table 2).

Fourteen hybrid combinations presented positive GCA values in MFPR, with emphasis on combinations BGU-13 x BGU-36 and BGU-1 x IPR Campos Gerais, which recorded the greatest magnitudes (Table 3). Cabralet al. (2011) reported that cultivars with the greatest plant height are desirable, since plant height has a positive and significant relation with grain yield.

If the aim of the breeding program is to develop greater stem diameter cultivars in MSD, combinations BGU-25 x BGU-13 (1.3689), IPR Uirapuru x BGU-7 (0.9081) and IPR Uirapuru $x$ BGU-13 (0.3209) are the most viable options, since they present the highest positive SCA values (Table 3). Among all these combinations, the ones including parent IPR Uirapuru should be given priority due to its higher GCA estimates (Table 2).

In MLLP, combinations BGU-1 x BGU-25 (0.3408) and IPR Uirapuru x BGU-13 (0.3270) recorded the greatest SCA positive effects (Table 3). Thus, these combinations should be favored if the intension is to develop plants that have longer bean pods.

Combinations showing higher SCA in TNPP were BGU-25 x BGU-13, IPR Uirapuru x BGU-7, IPR Uirapuru x BGU-1, BGU-7 x BGU-1, BGU-13 x BGU-36, IPR Uirapuru x IPR Campos Gerais, BGU-1 x BGU-36 and BGU-36 x IPR Campos Gerais (Table 3). Among all these parents, IPR Uirapuru and BGU-7 presented the highest GCA estimates (Table 2) since they participated in 50\% of the combinations recording the highest positive estimates and the second combination presenting the highest SCA estimate.

Eleven combinations presented positive SCA values in MNSPPL, and the greatest magnitudes among them were shown by combinations BGU-25 x BGU-36, BGU-1 x BGU13, IPR Uirapuru x BGU-1 and BGU-1 x IPR Campos Gerais (Table 3). However, only parents IPR Uirapuru and BGU-7 presented positive GCA values (Table 2).This made the best combination, composed of these two parents; this combination recorded an SCA value 35.4013 (Table 3). Griffing (1956) emphasizes that the best combination must be the one presenting the highest SCA, whose parents presented high GCA scores.

Parent BGU-36 showed the highest positive GCA magnitude in mean weight of 50 seeds (Table 2). This result was expressed in SCA, in which combinations between BGU-7 and BGU-13, and BGU-36 presented the greatest SCA magnitudes: 2.7246, 2.1782, respectively (Table 3 ). 
Table 3 - Estimates of specific combining ability effects ( $S_{\mathrm{ii}}$ and $S_{\mathrm{jj}}$ ) on the 11 variables: mean number of days to emergence (EMERG), mean number of days to blooming (BLOOM), mean insertion height of the first pod (INSHEI), mean final plant height (MFPR), mean stem diameter (MSD), mean length of the pods (MLLP), mean number of pods per plant (MNPP), mean number of seeds per plant (MNSPPL), mean number of seeds per pod (MNSP), mean weight of 50 seeds (MWS) and mean grain production (GP) in the common bean. Standard deviations (SD) of the effects of two $\mathrm{F}_{1}$ with, and without, common parent between two parents resulting from diallel crossing between seven parents.

\begin{tabular}{|c|c|c|c|c|c|c|c|c|c|c|c|}
\hline \multirow{2}{*}{$\begin{array}{c}\text { Hybrid } \\
\text { combinations } \\
\left(\mathrm{s}_{\mathrm{ii}} \mathrm{ands}_{\mathrm{ij}}\right)\end{array}$} & \multicolumn{11}{|c|}{ Assessed variables } \\
\hline & EMERG & BLOOM & INSHEI & MFPR & MSD & MLLP & TNPP & MNSP & MNPPL & MWS & GP \\
\hline $1 \times 1$ & -0.2077 & -0.4000 & -5.4481 & -0.4487 & -0.2407 & -0.3983 & -4.7986 & -0.1410 & -25.6375 & -1.3071 & -4.6485 \\
\hline $1 \times 2$ & -0.3325 & 0.2777 & -2.2182 & -0.1291 & 0.9081 & 0.1028 & 7.7681 & 0.0109 & 35.4013 & -0.5608 & 5.5026 \\
\hline $1 \times 3$ & 0.3168 & 1.9666 & -4.0371 & 0.3976 & 0.1707 & 0.2706 & 4.1347 & 0.5557 & 11.7013 & 2.0357 & 4.1888 \\
\hline $1 \times 4$ & 0.3257 & -0.2000 & 3.2596 & 0.3446 & -0.5277 & -0.0230 & -0.3319 & -0.0649 & 6.3180 & -0.2568 & -0.6217 \\
\hline $1 \times 5$ & 0.1754 & 0.5333 & 4.9852 & 0.3870 & 0.3209 & 0.3270 & -0.6653 & 0.2225 & 5.9291 & 1.3819 & 1.1136 \\
\hline $1 \times 6$ & -0.0429 & -1.6667 & 7.6395 & 0.0435 & -0.3319 & 0.1620 & -2.0208 & -0.5083 & -20.5431 & 0.7482 & -0.4083 \\
\hline $1 \times 7$ & -0.0271 & -0.1112 & 1.2673 & -0.1158 & -0.0589 & -0.0429 & 0.7125 & 0.0665 & 12.4680 & -0.7342 & -0.4724 \\
\hline $2 \times 2$ & -0.0075 & 0.3555 & -4.6884 & -0.2586 & -0.0152 & -0.2590 & -3.3653 & 0.0757 & -18.1098 & -1.3984 & -3.7792 \\
\hline $2 \times 3$ & 0.1579 & -0.1556 & -1.1572 & 0.2882 & -0.1326 & 0.1657 & 2.9514 & -0.2294 & 14.3402 & 1.2220 & 2.4045 \\
\hline $2 \times 4$ & -0.1162 & 0.0777 & 4.6395 & 0.3542 & -0.2935 & 0.2251 & -0.3653 & 0.0920 & 1.3569 & -0.1694 & -0.1269 \\
\hline $2 \times 5$ & 0.7505 & 0.9111 & 1.0151 & 0.2425 & -0.3233 & 0.0841 & -0.1486 & -0.0236 & 3.4680 & 0.7772 & -1.7263 \\
\hline $2 \times 6$ & 0.0072 & -0.4889 & 9.8504 & 0.1331 & -0.3077 & -0.0769 & -3.1042 & -0.2304 & -17.9542 & 2.7246 & 1.5614 \\
\hline $2 \times 7$ & -0.4520 & -1.3334 & -2.7528 & -0.3713 & 0.1793 & 0.0172 & -0.3708 & 0.2304 & -0.3931 & -1.1969 & -0.0568 \\
\hline $3 \times 3$ & 0.7232 & 0.5333 & -1.0761 & -0.3540 & 0.2306 & -0.6095 & -1.1819 & -0.7235 & -13.6098 & -0.6246 & -2.0004 \\
\hline $3 \times 4$ & -0.7749 & -0.8334 & 2.3706 & -0.2230 & -0.1873 & 0.3408 & -2.6486 & 0.2569 & -4.7931 & -0.5620 & -0.9248 \\
\hline $3 \times 5$ & -0.0831 & -0.1000 & -2.6538 & -0.3747 & -0.1842 & -0.0222 & -1.8319 & 0.8203 & -15.0319 & -0.6803 & -2.9226 \\
\hline $3 \times 6$ & -1.1435 & -1.6000 & -0.4995 & 0.2119 & 0.0670 & 0.2698 & 0.6125 & -0.3505 & 15.6958 & -0.7780 & 2.8961 \\
\hline $3 \times 7$ & 0.0803 & -0.3445 & 8.1293 & 0.4385 & -0.1950 & 0.1940 & -0.8542 & 0.3943 & 5.3069 & 0.1160 & -1.6011 \\
\hline $4 \times 4$ & 0.5590 & 1.3000 & -0.3826 & -0.4600 & -0.0628 & -0.2828 & -2.3153 & -0.2868 & -16.0764 & -0.3164 & -2.3866 \\
\hline $4 \times 5$ & 0.4507 & 1.0333 & -3.9070 & -0.2467 & 1.3689 & -0.0988 & 9.1513 & -0.4244 & 32.0347 & -0.5188 & 5.7365 \\
\hline $4 \times 6$ & -0.3846 & -1.5667 & -8.3777 & 0.2809 & 0.1451 & 0.1852 & -1.1042 & 0.8339 & 0.5625 & 0.1836 & 0.0542 \\
\hline $4 \times 7$ & -0.6188 & -1.1112 & 2.7801 & 0.4105 & -0.3799 & -0.0637 & -0.0708 & -0.1194 & -3.3264 & 1.9561 & 0.6615 \\
\hline $5 \times 5$ & -0.1745 & -0.6334 & -4.1315 & -0.4334 & -0.3799 & -0.2058 & -3.2319 & -0.2289 & -13.5042 & -1.8411 & -4.4773 \\
\hline $5 \times 6$ & -1.0928 & -1.0334 & 5.1229 & 0.5002 & 0.1173 & -0.1088 & 0.9625 & -0.3397 & -0.7764 & 2.1782 & 3.5769 \\
\hline $5 \times 7$ & 0.1480 & -0.0778 & 3.7006 & 0.3589 & -0.3063 & 0.2303 & -1.0042 & 0.2031 & 1.3847 & 0.5438 & 3.2167 \\
\hline $6 \times 6$ & 1.3719 & 3.2666 & -7.7728 & -0.4473 & 0.2659 & -0.3018 & 2.1069 & 0.1905 & 8.8013 & -1.6174 & -4.1815 \\
\hline $6 \times 7$ & -0.0873 & -0.1778 & 1.8100 & -0.2746 & 0.0129 & 0.1723 & 0.4403 & 0.2125 & 5.4125 & -1.8219 & 0.6829 \\
\hline $7 \times 7$ & 0.4784 & 1.5777 & -7.4672 & -0.2229 & 0.3739 & -0.2536 & 0.5736 & -0.4949 & -10.4264 & 0.6207 & -1.2153 \\
\hline SD (sii-sij) & 0.2232 & 0.4813 & 4.0272 & 0.1136 & 0.1768 & 0.1470 & 1.8672 & 0.2941 & 8.7245 & 0.7798 & 1.7767 \\
\hline SD (sij-sik) & 0.2824 & 0.6088 & 5.0941 & 0.1437 & 0.2236 & 0.1860 & 2.3619 & 0.3720 & 11.0357 & 0.9863 & 2.2474 \\
\hline SD (sij-skl) & 0.2642 & 0.5694 & 4.7651 & 0.1344 & 0.2092 & 0.1739 & 2.2093 & 0.3480 & 10.3229 & 0.9226 & 2.1023 \\
\hline
\end{tabular}

*Parents: 1-IPR Uirapuru, 2-BGU-7, 3-BGU-1, 4-BGU-25, 5-BGU-13, 6-BGU-36 e 7-IPR Campos Gerais. 
Twelve hybrid combinations showed positive SCA values in GP (Table 3). Among these combinations, the following have one parent with positive GCA values: IPR Uirapuru x BGU-7, IPR Uirapuru x BGU-1, IPR Uirapuru x BGU-13, BGU-7 x BGU-36, BGU-1 x BGU-36, BGU-25 x BGU-36, BGU-13 x BGU-36 and BGU-36 x IPR Campos Gerais. All these combinations tend to reinforce the selection of promising strains in order to produce high grain weight. However, the combinationBGU-25 x BGU-13 presented the highest SCA, even though none of the parents presented positive GCA values. The SCA value in this combination can be explained by a high genetic complementation degree between parents (Idahosa and Alika, 2013).

Based on the set of assessed variables, we conclude that the hybrid combinations IPR Uirapuru x BGU-7, IPR Uirapuru x BGU-1, BGU-7 x BGU-1, BGU-25 x BGU-13 and BGU-13 x BGU-36 are the most favorable for the generation of segregating populations for the production of highly productive strains.

\section{CONCLUSIONS}

Additive gene effects prevailed in the expression of INSHEI and MLLP. Nonadditive gene effects prevailed in the expression of EMERGE, MFPR, TNPP, MNSP, MNSPPL, MWS and GP.

Local varieties presented good general and specific combinations.

Parents IPR Uirapuru and BGU-36 presented the best combining ability in most of the variables, and hybrid combinations IPR Uirapuru x BGU-7, IPR Uirapuru x BGU-1, BGU-7 x BGU-1, BGU-25 x BGU-13 and BGU-13 x BGU-36 were the most promising for the development of highly productive strains.

\section{ACKNOWLEDGMENTS}

The authors are grateful to Fundação de Amparo à Pesquisa do Estado de Mato Grosso (FAPEMAT) for granting a scholarship.

\section{CONFLICT OF INTEREST}

All authors declare they have no conflicts of interest.

\section{REFERENCES}

Arunga EE, Van Rheenen HA and Owuoche JO (2010). Diallel analysis of Snap bean (Phaseolus vulgaris L.) varieties for important traits. Afr. J. Agric. Res. 5:951-1957. https://doi.org/10.5897/AJAR09.082.

Barelli MAA, Gonçalves-Vidigal MC, Amaral Júnior AT do, Vidigal Filho, OS et al., (2000). Diallel analysis of the combining ability of common bean (Phaseolus vulgaris L.) cultivars. Braz. arch. biol. technol. 43:409-414. http://dx.doi.org/10.1590/S1516-89132000000400009.

Bitocchi E, Bellucci E, Giardini A, Rau Det al., (2013). Molecular analysis of the parallel domestication of the common bean (Phaseolus vulgaris) in Mesoamerica and the Andes. NewPhytol, 197:300-313.https://doi.org/10.1111/j.14698137.2012.04377.x.

Broughton WJ, Hernández G, Blair M, Beebe S et al., (2003). Beans (Phaseolus spp.) - model food legumes. Plant Soil. 252:55-128. https://dx.doi.org/10.1023/A:1024146710611.

Cabral PDS, Soares RCB, Lima ABP, Soares YJ et al. (2011). Análise de trilha do rendimento de grãos de feijoeiro (Phaseolus vulgaris L.) e seus componentes. Rev. Ciênc. Agron. 42:132-138. http://dx.doi.org/10.1590/S1806$\underline{66902011000100017 .}$. 
Carvalho IR, Nardino M, Ferrari M, Pelegrin AJ et al., (2016). Genetic variability among common black bean (Phaseolus vulgaris L.) accessions in southern Brazil. Aust. J. Crop. Sci. 10:1474-1483. https://10.21475/ajcs.2016.10.10.p7786.

Cruz CD, Carneiro PCS. And Regazzi AJ (2014). Modelos biométricos aplicados ao melhoramento genético. (v. 2, $3^{\mathrm{a}}$ ed). Viçosa, MG. Editora UFV, Universidade Federal de Viçosa. 668p.

Cruz CD (2013). GENES - a software package for analysis in experimental statistics and quantitative genetics. Acta Sci. Agron. 35:271-276. http://dx.doi.org/10.4025/actasciagron.v35i3.21251.

Demelash BB (2018). Common Bean Improvements Status (Phaseolus vulgaris L.) in Ethiopia. Adv. Crop. Sci. Tech. 2:1-6. https://doi.org/10.4172/2329-8863.1000347.

Fess TL, Kotcon JB and Benedito VA (2011). Crop Breeding for low input agriculture: A sustainable response to feed a growing word population. Sustainability 3:1742-1772. https://doi.org/10.3390/su3101742.

Gonçalves JGR, Chiorato AF, Silva DA, Esteves JAF, et al., (2015). Análise da capacidade combinatória em feijoeiro comum submetido ao déficit hídrico. Bragantia 74:149-155. http://dx.doi.org/10.1590/1678-4499.0345.

Gonçalves-Vidigal MC, Silvério L, Elias HT, Vidigal Filho PS, et al. (2008). Combining ability and heterosis in common bean cultivars. Pesq. agropec. bras. 43: 1143-1150. http://dx.doi.org/10.1590/S0100204X2008000900007.

Griffing JB (1956). Concept of general and specific combining ability in relation to diallel systems. Aust. J. Biol. Sci.9:463-493. https://doi.org/10.1071/BI9560463.

Idahosa AO and Alika JE (2013). Diallel analysis of six agronomic characters in Vignaun guiculata genotypes. Afr. J. Plant Breed. 1:1-7.

Krause W, Rodrigues R. and Leal NR (2012). Capacidade combinatória para características agronômicas em feijão-devagem. Rev. Ciênc. Agron. 43:522-531.http://dx.doi.org/10.1590/S1806-66902012000300015.

Moura LM, Carneiro PCS, Vale NM, Barili LD, et al., (2016). Diallel analysis to choose parents for black bean (Phaseolus vulgaris L.) breeding. Genet. Mol. Res. 15:1-12. http://dx.doi.org/10.4238/gmr.15038574.

Neves SMA, Nunes MCM and Neves RJ (2011). Caracterização das condições climáticas de Cáceres/MT-Brasil, no período de 1971 a 2009: subsídio às atividades agropecuárias e turísticas municipais. Bol. Goia. Geogr. 31:55-68. https://doi.org/10.5216/bgg.v31i2.16845.

Rocha F, Stinghen JC, Gemeli MS, Coimbra JLM, et al., (2014). Análise dialélica como ferramenta na seleção de genitores em feijão. Rev. Ciênc. Agron. 45:74-81. http://dx.doi.org/10.1590/S1806-66902014000100010.

Sprague GF and Tatum LA (1942). General vs. specific combining ability in single crosses of corn. J. Amer. Soc. Agron. 34:923-32. http://dx.doi.org/10.2134/agronj1942.00021962003400100008x.

Talukder ZI, Anderson E, Miklas PN, Blair MW, et al., (2010). Genetic diversity and selection of genotypes to enhance $\mathrm{Zn}$ and Fe content in common bean. Can. J. Plant Sci. 90:49-60. https://doi.org/10.4141/CJPS09096.

Trindade RS, Rodrigues R, Amaral Junior AT, Gonçalves LSA, et al., (2015). Combining ability for common bacterial blight resistance in snap and dry bean (Phaseolus vulgaris L.). Acta Sci. Agron.37:37-43. http://dx.doi.org/10.4025/actasciagron.v37i1.16505.

Tsutsumi CY, Bulegon JG and Piano JT (2015). Melhoramento genético do feijoeiro: avanços, perspectivas e novos estudos, no âmbito nacional. Nativa, 3:217-223. http://dx.doi.org/10.14583/2318-7670.v03n03a12.

Velho LPS, Gemeli MS, Trevisani N, Pereira TCV, et al.,(2017). Phenotypic correlation and direct and indirect effects of aerial part components with root distribution of common bean. Pesq. agropec. bras. 52:328334.http://dx.doi.org/10.1590/s0100-204x2017000500006.

Voysest O, Valência MCandAmezquita MC (1994). Genetic diversity among Latin American Andean and $\begin{array}{lllll}\text { Mesoamerican common } & \text { bean } & \text { cultivars. } & \text { Crop } & \text { Sci.1100-1110. }\end{array}$ http://dx.doi.org/10.2135/cropsci1994.0011183X003400040049x 